DOI https://doi.org/10.30929/2307-9770.2020.08.03.02

UDC 621.313.333.02

\title{
Language Adaptation of Turkisms in English
}

\author{
Khamitova Sh. ", Adilova A. \\ E. A. Buketov Karaganda State University, Karaganda, Kazakhstan
}

Received: $25.06 .2020 \quad$ Accepted: 20.09 .2020

\begin{abstract}
One of the most important indicators of the adaptation of Turkic borrowing in English is their allocation in different dictionaries of English (explanatory, etymological, phraselogical), as well as their use in different works of fiction. Linguistic contacts manifest themselves in the interaction of linguistic, cultural and historical factors and represent an essential process in intercultural communication. Turkic lexical elements, actively used in various languages as a language mechanism, require special attention. A comparison of different languages shows that borrowing is a universal fact of language, the linguistic essence of which allows to determine the absolute or relative chronology of their entry into the system of different languages. Turkisms closely related to the lexico-semantic system of the recipient language expands the body of language units of English and other languages, indicating the paths of penetration and the degree of adaptation. This takes into account the patterns of lexical and phonetic potential of the language. Turkic borrowing includes not only Turkic words, but also lexical elements of Arabic and Mongolian, Persian, Tatar, Uzbek, Kazakh origin, which have penetrated English through many Turkic languages and have been reflected in English lexicographic sources. Turkism thus refers to words included in English from Turkic languages or through Turkic languages regardless of the source of the mutual relationship, i.e. words having a Turkic stage in their history.
\end{abstract}

Key words: semantic categories of Turkic borrowing, assimilation, oriental words, borrowing process, cultural picture of the world, English language dictionaries.

\section{Мовна адаптація тюркізмів в англійській мові}

\author{
Хамітова Ш., Аділова А.
}

Карагандинський університет імені академіка Є. А. Букетова, Караганда, Казахстан

\begin{abstract}
Анотація. Одним з найважливіших показників адаптації тюркських запозичень в англійській мові $\epsilon$ їх виділення в різних словниках англійської мови (тлумачних, етимологічних, фрразеологічних), а також їх використання в різних художніх творах. Лінгвістичні контакти проявляються у взаємодії мовних, культурних і історичних чинників і являють собою важливий процес міжкультурного спілкування. Особливої уваги потребують тюркські лексичні елементи, які активно використовуються в різних мовах як мовний механізм. Порівняння різних мов показує, що запозичення - це універсальний факт мови, лінгвістична сутність якого дозволяє визначити абсолютну або відносну хронологію їх входження в систему різних мов. Тюркізми, тісно пов'язані з лексико-семантичною системою мови-реципієнта, розширюють сукупність мовних одиниць англійської та інших мов, вказуючи шляхи проникнення і ступінь адаптації. При цьому враховуються закономірності лексичного і фронетичного потенціалу мови. Тюркські запозичення включають не тільки тюркські слова, але і лексичні елементи арабського і монгольського, перського, татарського, узбецького, казахського походження, які проникли в англійську мову через багато тюркські мови і знайшли відображення в англійських лексикографічних джерелах. Таким чином, тюркизм відноситься до слів, включеним в англійську мову з тюркських мов або через тюркські мови незалежно від джерела взаємин, тобто слова, що мають тюркський етап у своїй історії.
\end{abstract}

Ключові слова: семантичні категорії тюркських запозичень, асиміляція, східні слова, процес запозичення, культурна картина світу, словники англійської мови.

\footnotetext{
Corresponding Author: Khamitova Shaizat Amantayevna. E-mail: shaizat85@mail.ru. Karaganda state industrial university, Republic Ave. 30, Temirtau, Karaganda region, Kazakhstan, 101400.

Biдnовідальний автор: Хамитова Шайзат Амантаевна. E-mail: shaizat85@mail.ru Карагандинский индустриальный университет, пр. Республики 30, Темиртау, Карагандинская область, Казахстан, 101400.
} 


\title{
Языковая адаптация тюркизмов в английском языке
}

\author{
Хамитова Ш., Адилова А. \\ Карагандинский университет имени академика Е. А. Букетова, Караганда, Казахстан
}

\begin{abstract}
Аннотация. Одним из важнейших показателей адаптации тюркских заимствований в английском языке является их выделение в различных словарях английского языка (толковых, этимологических, фразеологических), а также их использование в различных художественных произведениях. Лингвистические контакты проявляются во взаимодействии языковых, культурных и исторических факторов и представляют собой важный процесс межкультурного общения. Особого внимания требуют тюркские лексические элементы, активно используемые в различных языках как языковой механизм. Сравнение разных языков показывает, что заимствование - это универсальный факт языка, лингвистическая сущность которого позволяет определить абсолютную или относительную хронологию их вхождения в систему разных языков. Тюркизмы, тесно связанные с лексико-семантической системой языка-реципиента, расширяют совокупность языковых единиц английского и других языков, указывая пути проникновения и степень адаптации. При этом учитываются закономерности лексического и фонетического потенциала языка. Тюркские заимствования включают не только тюркские слова, но и лексические элементы арабского и монгольского, персидского, татарского, узбекского, казахского происхождения, которые проникли в английский язык через многие тюркские языки и нашли отражение в английских лексикографических источниках. Таким образом, тюркизм относится к словам, включенным в английский язык из тюркских языков или через тюркские языки независимо от источника взаимоотношений, то есть слова, имеющие тюркский этап в своей истории.

Ключевые слова: семантические категории тюркских заимствований, ассимиляция, восточные слова, процесс заимствования, культурная картина мира, словари английского языка.
\end{abstract}

\section{Introduction}

Language is a historically developing phenomenon associated with the evolution of society. In the course of formation, the language transmits national cultural values, adapts the treasures of another culture, as well as the words that accompany them. When entering the system of the receiving language, borrowing is included in the transformation process. in other words, when a foreign language element is inserted into another language system, it adapts to the recipient language system. at first glance, the problem of assimilation of borrowings is contradictory in many aspects. The discrepancy is observed both at the stage of creating classifications, types of borrowings, and at the level of designating the borrowing mechanism itself and highlighting the stages, types, and levels of adaptation of the borrowed vocabulary in the successor language.

The process of borrowing vocabulary in certain historical epochs and in different languages requires indepth study. therefore, this work is devoted to the language adaptation of turkisms in English on the material of different lexicographic sources. It is known that the language was formed as a result of centuries of joint labor activity of ancestors and as a consequence of the constant need for communication associated with it. In the history of mankind, there are various forms and ways of mutual influence of languages. The study of the stages of this interaction is of fundamental importance for characterizing the processes of development and enrichment and increasing the vocabulary of a language as a result of borrowing foreign language elements. Therefore, borrowing in the context of intercultural communication is a natural result of any communication between peoples. The relevance of this work is determined by the increased interest of linguists in Eastern languages and their cultures in the aspect of intercultural communication. Special attention should be paid to the Turkic lexical elements that are so actively used in various languages.

As Damaris W. Karũrũ (2013) said in his article about borrowings and communication in languages that from the early time languages existed to communicate; borrowing, therefore, occurs out of necessity or need where a language does not have a readily available word for something. Other reasons for borrowing include prestige and foreign influence. Borrowing occurs when speakers of a given language have had some contact with another/other language(s).

Amount of scientists such as (Showqi Bahumaid,2015, Damaris W. Karũrũ(2013) Trophimova S.M, Bold L (2018), N.R. Oynotkinova (2018), Alfiya N. Zaripova Anna, D. Fominykh (2015) Esma Fatıma Bilgin,, Ayşe Berrin YANIKOĞLU (2018), Ishegulova A.M (2018), Adilova A.S.(2018) on linguistics dedicate their works for investigation loanwords in whole, nowadays there are a lot of new material currently (Elina 
Stepanyan,2018) which indicates the process assimilation of borrowings and about intercultural communication in the language of the recipient on linguistics.

In this case we can also say that our country Kazakhstan is multiethnic state that's very important factor of interaction of the Kazakh, Russian and English languages. As the professor of Karaganda state university Adilova A.S.(2018) writes in her article «On the verbal structure of Kazakh media texts» that interaction of the Kazakh and Russian languages is observed in many spheres. One of them - the sphere of mass communication which means perform various functions in society. Media texts of the main Kazakhstan news portals providing materials in Russian differ in features. Further said importance of words and word combination like Ratel.kz, Tengrinews.kz, EXPO-2017, no need to translate into state language or Russian.

There are about 7000 languages spoken all over the world. It has been discovered that when languages come into contact, there is transfer of linguistic items from one language to another due to the borrowing of words (Kachru, 1989).

The process of borrowing vocabulary in certain historical epochs and in different languages requires indepth study. therefore, this article discusses the language adaptation of turkisms in English on the basis of lexicographic sources. It is known that the language was formed as a result of centuries of joint labor activity of ancestors and as a consequence of the constant need for communication associated with it. In the history of mankind, there are various forms and ways of mutual influence of languages. The study of the stages of this interaction is of fundamental importance for characterizing the processes of development and increasing the vocabulary of a particular language as a result of borrowing foreign language elements. «Every nation can and should learn from others» so borrowing in the context of intercultural communication is a natural result of any communication between peoples

In the opinion of Hosam M. Darwish, 2015, it is considered quite normal for languages to borrow words from other languages. When a language takes words from other languages, these - new arrivals are usually called borrowings or loan words. According to Bynon (1977), this term is a loan translation of German «lehnwort» whereas Abdel Rahman (1991) thinks that this term is misleading and unsatisfactory, but he disagrees with Banyon who believes that the donor language does not get its borrowed word back. It is believed that the main reason of loaning is the need to acquire new vocabulary or lexical items for new places, things and concepts. Langacker (1967) argues that loaning existing words from another language is easier than creating ones. The cultural influence plays an important role in the path of borrowing words.

According to W. B. Lockwood (1999) on the history of English language has borrowed thousands of words and word combinations from practically each language spoken in the world.

The relevance of this work is determined by the interest of linguists in Eastern languages and their cultures in the aspect of intercultural communication. Special attention should be paid to the Turkic lexical elements Nevskaya I. Ayna (2015), Oinotkinova N.R.(2018) that are so actively used in various languages in order to identify the interaction of language mechanisms. Thus, we understand by Turkism (Turkic lexical elements) owls that entered the English dictionary from the Turkic languages or through the Turkic languages, regardless of the source of borrowing, that is, words that have a Turkic stage in their history, for example: Turkic language-English; another language-Turkish language-English; second language-Turkish languageother language-English. As you can see, the Turkic borrowings include not only native Turkic words and their derivatives, but also words and lexical elements of Arabic, Persian, and Mongolian origin, Trophimova S .M, Bold $L$ (2018) which penetrated into the English language through the Turkic languages and found reflection in English lexicographic sources.

Problem Statement. According to historical and scientific data, there is no pure language formed from the words of only one nation. Due to various objective reasons, the language is not preserved to the same extent as it is constantly evolving, cannot remain unchanged, corresponding to modern requirements and needs of application. This does not apply to English, which is currently considered a pluricentric language. As S.V. Grinev-Grinevich (2015) thinks, borrowing contributes to the improvement and development of the language, making it "accurate in expression, emotionally expressive and stylistically diverse" The formation of terminology of many national languages has "one common feature - a tendency to borrow from a wide range of rather limited range of developed languages" Grinev-Grinevich,( 2015). Among international terms there are words that have a narrow scope of distribution, limited by the scope of one professional specialty. Hypothesis 
of research foreign vocabulary in economic terminology of the German, Russian and Tatar languages is characterized by common areas of borrowing as well as by non-comparable sources of borrowing.

Research Questions. The sources of the research were various types of dictionaries such as etymological, foreign words, explanatory, bilingual, separate articles of various issues of the magazine ,works of domestic and foreign authors on history, as well as excerpts from a work of art.

Purpose of the Study. The purpose of the research is to define language adaptation of Turkisms in English vocabulary. It is aimed to characterize the features of the functioning of Turkisms at different stages of the English language (lexical and word-forming), revealing the degree of their development. Tenses in the English language are different, in different volumes, due to different Turkic words, that among the driveways is known, words in the case. The reasons for borrowing words and phrases in different historical periods of formation and development of the lexical and semantic system of a language are different. External, nonlinguistic reasons for borrowing words from a single language include the presence of more or less close political, economic, industrial, and cultural ties between native-speaking peoples, the need to nominate new subjects, processes, and concepts, the nation's innovation in a particular field of activity, and the authority of the source language. Among the internal (language) reasons, the following are distinguished: the tendency to save language resources and to eliminate homonymy and polysemy of the original word, the accumulation in the borrowing language of the same type of words, which is planned to isolate one of these elements. In the lexical fund of the English language, (Minulina E.I, 2015) there is reason to wonder where the Turkic borrowed words come from, since England is not nearby to the Turkic-speaking states, neither religions nor languages are thoroughly far apart. Also, Albanian, German, Latin, Spanish, Italian, Hungarian became intermediate languages for the penetration of Turkic words into English. In addition, several words of Turkic origin entered English thanks to Eastern European languages such as Russian and Polish.

\section{Materials and Methods}

Research Methods. To solve the definite problem set out a number of research methods are used to investigate the material. The materials of research are small group of Turkic borrowings taken out from lexicographical sources (English -Russian phraseological dictionaries of different years). Comparative method is used (comparison of Turkic elements in English language) during the writing the article.

\section{Results}

Findings. Many Turkic words came in English language through other languages, most often throughout French, for example, the words kiosk, kumiss, macrame. Also, Albanian, German, Latin, Spanish, Italian, Hungarian, and Serbo-Croatian became intermediate languages for the penetration of Turkic words into English. Meanwhile, the history of words leads us to the epochs of the Crusades, to the times of long and dangerous journeys to distant countries, to the caravans with Eastern goods that followed the great «Silk Road». During the Mongol expansion, the native language and the language of the Mongol conquerors appeared in the minds of the Turkic-speaking natives of the Central Asian steppes in relation to the «additional distribution». In higher spheres, for example, in the political, socio-economic situation, the local population began to use the Mongolian language of the newcomers, while in lower spheres-at the household, family levels - they still communicated in their native Turkic language. Over time, as modern research shows, Oinotkinova R.S. (2018) the problem of choosing the language of everyday, family communication among the bilingual population is solved in favor of a more prestigious language. The social top of the Turkic population was the fastest to switch to the Mongolian language, and the native language was the longest preserved among the social lower classes.

According to the investigators Esma Fatıma Bilgin, Ayşe Berrin (2018) Turkish is an agglutinative language where new words are formed by adding suffixes to the end of root words. There are grammatical rules (i.e. morphotactics) governing which suffixes may follow which other, and in what order, but the number of possible words that may be generated by adding suffixes is practically infinite, with application of some suffixes repeatedly. As such, a finite-size lexicon for Turkish would miss a significant percentage of Turkish words, causing a high out-of-vocabulary (OOV) rate. This makes lexicon-based large vocabulary text recognition approaches unsuitable for Turkish, or other agglutinative languages 
In the XI-XIII centuries, the Turks entered the English language in the old French language, and the direct connection between the English and the Turks began when the English feudal lords took part in the Crusades with their fighters.Since the establishment of direct relations between England and Turkey, as well as between Turkey and Russia, starting from the XVI century, new direct loanwords from the Turkic languages appeared in English. The majority of Turkic loanwords in the English language-the exotic or ethnographic connotation lexicon. They have no analogues in English, relations with derived words are not transparent and are used in general to describe the fauna, flora, household, moral, political and social life, administrative and territorial structure of the Turkic regions. But a number of Turkic words are still part of the vocabulary used. Some Turkic words had new meanings that were not related to their etymology.

The materials of the research are groups of Turkic borrowings that are taken out from the lexicographical sources. The materials also comprise a block of word combinations found out in literary texts and lexico-graphical sources of A.S. Hornby [Hornby A. S., 1992.]. In the interpretation dictionary of English A.S. Hornby were established about 44 formants of Turkic origin and analyzed 118 lexical units of Turkic origin recorded in Webster's etymological dictionary "Webster's International Dictionary». The results obtained during the analysis of Turkisms contribute to the solution of general or specific issues in the process of adaptation of language units and can also be used in comparative typological studies, complementing the actual material of intercultural communication of the interaction of languages in word formation, translation theory and linguo-country studies. Trying to classify them by semantic characteristic allowed to define the following semantic series: "Human» - ayatollah, bashi-bazouk, beebee, mullah; "Life» - angora, macramé; «Food» - caviar, kefir, yogurt; «Clothes» - caftan, gilet; «Plants» - bergamot, taiga; «Animals» - jackal, irbis; « Tool punishment / Weapon » - kurbash, yataghan. (Webster's New World Dictionary,1999).

As a result of analysis of Turkic borrowing were established about 46 word formation with the word turkey and 21 word-formation with word Turkish, for instance: turkey-cock, turkey foot, turkey wing, Turkish delight, Turkish knot. (C. T. Onions, 2004). There are several words and word combinations with the beginning of word Turkey from the English Russian phraseological dictionary published in1984 by A.V. Kunin,( Kunin A.V.,1984) had explained further:

\section{Turk-турок, турчанка 1) уoung turk- ист.младотурок; \\ 2) шутл. непослушный ребенок. \\ 3) през. дикий, неуправляемый человек}

turkey- индюк, амер. жаргон-неудача, провал

turkey-buzzard зоол.грифр-индейка

Turkey -corn-кукуруза

turkey red- ярко красный цвет

turkey-hen-индейка

turkey-poult-индюшонок

Turkey-stone- оселок

Turkish-delight-рахат-лукум

Turkish towel-мохнатое полотенце

Turkic-тюркский

Turkism-турецкий образ жизни; divan-тахта, диван (законодательное, административное или судебное учреждение в некоторых странах мусульманского Востока), диван, сборник восточных стихов 
The word divan has different meanings such as judicial institution in some countries of the Muslim East, and like furniture. Here is an interesting information from (The Design History Society, 2010) published by Oxford University Press. The article studies the mutual factor of Ottoman Turkish and American interiors in the growth of soft furnishings. Soft furnishings is original in relation to it affects a direct and physical interaction between the part of furniture and the body, although at the same time it is a piece of public space where social interactions took place.

The concept of body convenience will provide as a common thread in understanding the origin of the expression "American style» in modern Turkish language and «the Turkish chairs» in Victorian American till 19th century. It is interesting that English vocabulary has several meanings using of words as sofa, ottoman and divan.

The analysis of some works of fiction also allows to complete that Turkic loan-words are often used in the following situations:

- to create a certain atmosphere that spreads and points out the specific features of the colorite of the countries of the East and Asia:

It was six in the morning when Mr. Parker Pyne left for Persia after a stop in Baghdad.

Completely mad. She lives there at Shiraz in a big native house. She wears Eastern dress.

A big divan was placed against the wall and on it reclines a striking figure

- to pose the historical setting and recreate historical realities, as in Christopher Marlo 's tragedy «The Great Tamerlan» (Vlasicheva V. V.,2012);

- using of Turkic borrowing in literary fiction:

\section{catch a Tartar}

1) встретить противника не по силам; получить решительный отпор,

2) Взять в жены сущую фурию, мегеру.

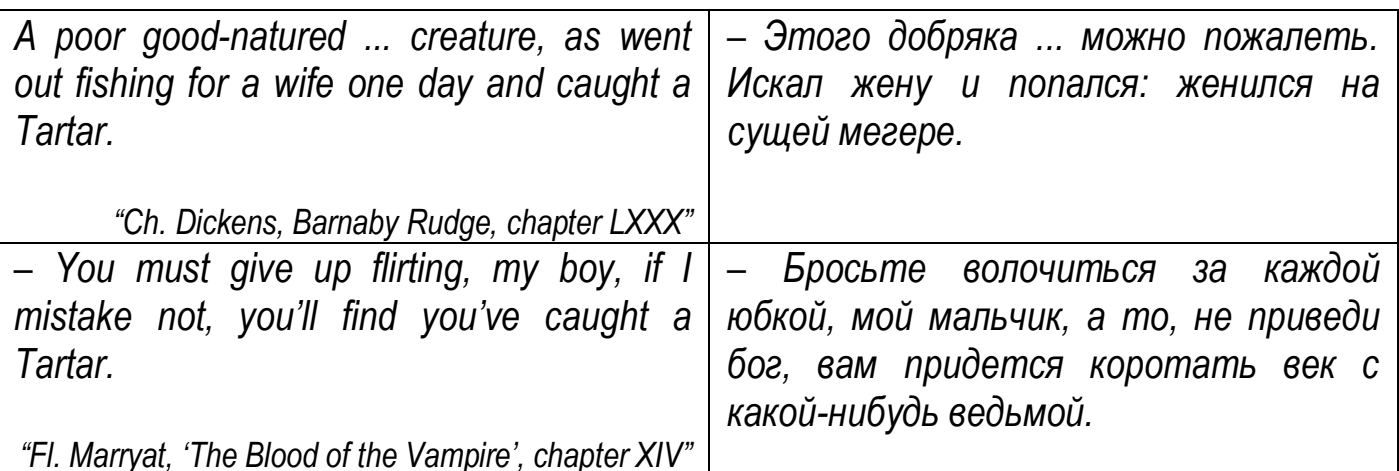

\section{cold turkey}

1) Adv, phr, американ. жарг. под влиянием минуты, не раздумывая; без подготовки, без предупреждения.

\begin{tabular}{|c|c|}
\hline $\begin{array}{l}\text { You said that you and Kirby went to see } \\
\text { Dr.Babb cold turkey, that you didn't } \\
\text { telephone or have any appointment. }\end{array}$ & $\begin{array}{l}\text { - Вы сказали, что вместе с Керби } \\
\text { отправились к доктору Бэббу, не } \\
\text { предупредив его о предстоящей } \\
\text { встрече. Вы не звонили доктору } \\
\text { заранее и не договаривались об этом } \\
\text { визите. }\end{array}$ \\
\hline
\end{tabular}

"E.S. Gardener, The Case of the Screaming Women', chapter V" 


\begin{tabular}{|l|l|}
\hline - He had been kicked out of NCO School & - Его вьгнали из сержантской школы, \\
point blank, cold turkey. & сразу, не предупреждения. [Кипіn A.V., \\
& 1984]$. \\
\hline "J. Jones, 'From here to Eternity', chapter XXXVIII" & \\
\hline
\end{tabular}

2) noun, амер. жарг. холодный, равнодушный человек.

\begin{tabular}{|c|c|}
\hline $\begin{array}{l}\text { He was ...what we call a grouch-face, a } \\
\text { drizzle-puss, a wet blanket, a cold turkey. } \\
\text { "E.S. Gardner 'Some Women Won't Wait' chapter }\end{array}$ & $\begin{array}{l}\text { - Бикнелл был ... ворчун, портящий } \\
\text { всем настроение, } \\
\text { равнодушный человек. }\end{array}$ \\
\hline
\end{tabular}

3) амер. жаргон легкая добыча, жертва, человек, которого ждет поражения или гибель; что-л. Провалившееся, не имевшее успеха

\begin{tabular}{|c|c|}
\hline $\begin{array}{l}\text { 'Sam' I said, 'I don't know where to find } \\
\text { anybody who would put money into a play } \\
\text { that's already a cold turkey' } \\
\quad \text { "E. Caldwell, 'Call It Experience', chapter XVIII" }\end{array}$ & $\begin{array}{l}\text { - Сэм, - заметил я, - не знаю, где мне } \\
\text { найти человека, который стал } \\
\text { финансировать уже один раз } \\
\text { провалившуюся пьесу. }\end{array}$ \\
\hline A cold turkey for the enemy & Легкая добьча для противников \\
\hline
\end{tabular}

4) жарг. амер. Лишение наркомана наркотиков (во время лечения); прекращение употробления наркотиков (без медицинского вмешательства)

\begin{tabular}{|l|l}
\hline Joe did a cold turkey & Джо бросил принимать наркотики. \\
\hline
\end{tabular}

\section{talk turkey}

разг. 1) вести деловую беседу.

\begin{tabular}{|c|c|}
\hline $\begin{array}{l}\text { 'You can have anything you care to ask } \\
\text { for. Anything,' he repeated. } \\
\text { 'Ah,' said Dr Obispo, 'now you're talking } \\
\text { turkey.' }\end{array}$ & $\begin{array}{l}\text { - Просите у меня все, что хотите, - } \\
\text { повторил мистер Стойт. } \\
\text { - Вот это деловой разговор, - сказал } \\
\text { доктор Обиспо. }\end{array}$ \\
\hline $\begin{array}{r}\text { "A. Huxley, 'After Many a Summer,' } \\
\text { part II, chapter. X" }\end{array}$ & \\
\hline
\end{tabular}

2) говорить прямо, начистоту.

\begin{tabular}{|l|l|}
\hline $\begin{array}{l}\text { I want to talk cold turkey to you, man to } \\
\text { man! }\end{array}$ & $\begin{array}{l}\text { - Я хотел поговорить с вами со всей } \\
\text { откровенностью, как мужчина с } \\
\text { мужчиной. }\end{array}$ \\
"K. Vonnegut, 'Cat'sCradle"
\end{tabular}

\section{Turkey -cock}




\begin{tabular}{|l|l|}
\hline - He was sorry for Mac Gown! There he & - Ему было жаль Мак-Гауна. Все вокруг \\
sat, poor devil!- with every one getting up & него встали, а бедняга сидел \\
all round him, still; and red as a turkey- & неподвижно, как красный рак. \\
cock. & "J. Galsworthy, 'The Silver Spoon', \\
part III, chapter VIII" & \\
\hline
\end{tabular}

\section{Discussion}

The study of foreign vocabulary more extensively, the study of linguistic borrowings, presents a serious interest for linguistic analysis and other sciences. Purely linguistic issues related to this area are connected with the issues of «purity» of vocabulary, and In many works, are reflected in conjunction with the problems of cultural and socio-economic contacts between countries and people. Historians, philologists, public figures, writers, critics have always been keenly interested in the processes of penetration of foreign vocabulary into given language and its further expansion and use, expressing their views on the acceptance or nonacceptance of certain words, and very often these statements and arguments go far beyond the linguistic sphere - expanding to the field of ideology, politics, sociology etc.

It is necessary to point out at this point of discussion, that the concept of borrowing indicates the process of moving different elements from one language to another. Different elements are understood as units of different levels of the structure of the languages - phonology, morphology, syntax, vocabulary and semantics.

\section{$\checkmark$ Conclusion}

Thus, as a result of communication with different cultures, it is observed that the Turkic borrowed words included in the English language not only enrich it with new concepts that do not have this culture, but also undergo morphological and phonetic changes, have lost their previous image and become an integral part of the vocabulary of English language.

The co-existence of different languages indicates that borrowing is a universal fact of language whose linguistic essence allows to determine the absolute or relative chronology and their entry into the system of different languages. Turkisms, closely related to the lexical and semantic system of the recipient language, expand the corpus of language units of English and other languages, indicating the ways of penetration and the degree of adaptation. this takes into account the regularities of the lexical and phonetic potential of the language. The intensity of contacts between the Turkic peoples and the English and the reflection of interaction processes in the English language contributes to the emergence of turkisms in certain cultural and historical conditions that are characterized by the presence of several thematic groups.

\section{References}

1. Adilova, A. S. (2018). On the verbal structure of Kazakh media texts. International scientific and theoretical conference "Language and Society Mat.", 311-316.

2. Karũrũ, Damaris W. (2013). Borrowing and Communication in Language: The Impact of morphological Adaptation Processes. Educational Journal Education and Research, 1(9), 1-14.

3. Stepanyan, E. (2018). A Survey on Loanwords and Borrowings and Their Role in the Reflection of Cultural Values and Democracy Development: the Armenian Paradigm. European Journal of Marketing and Economics, 1(2), 77 . Doi: https://doi.org/10.26417/ejme.v1i2.p77-86

4. Bilgin, Esma Fatıma, Yeşilyurt, Ayşe Berrin Yanikoğlu (2018). Large vocabulary recognition for online Turkish handwriting with sublexical units. Turkish Journal of Electrical Engineering \& Computer Sciences, 26(5), 2218-2231. Doi: https://doi.org/10.3906/elk-1801-234

5. Grinev-Grinevich S.V. (2015) Hypothesis of Research Foreign vocabulary in economic terminology of the German, Russian and Tatar languages, 4;113.

6. Hornby, A. S. (1992). Explanatory dictionary of the English language. Stavropol, Russia, 540. [in Russian]

7. Bikkinin, I. (1998). Turkic Borrowings in English [Tiurkizmy v angliiskom iazyke]. The Tatar Gazette [Tatarskaia gazeta], 13. URL: http://www.tatarica.narod.ru/world/language/tat_eng.htm (accessed 20.05.2020). [in Russian]

8. Ishegulova, A. M. (2018). Academic dictionary of Bashkir Language. Issues of lexicography [Akademicheskii slovar Bashkirskogo yazyka], 14, 68-79. 
9. Krysin, L. P. (2004). Russian word, one's own and another's: Research on the modern Russian language and sociolinguistics. Languages of Slavic culture, Moscow, 19.

10. Kunin, A. V. (1984). English-Russian phraseological dictionary. Rus. lang., Moscow, 944.

11. Kibrik, A. A. (Ed.), Beliaev, O. I. (Ed.), Koriakov, Iu. B. (Ed.), Mazurova, Iu. V. (Ed.), Markus, E. B. (Ed.), Rogova, N. V. (Ed.), Romanova, O. lo. (Ed.) (1997). Languages of the world [Yazyki mira]. Indrik, Moscow, 544.

12. Nevskaya, I. (2017). Role of religion in the Turkic World. Proceedings, 211-226.

13. Oinotkinova, N. R. (2018). Demonym " Aza» in the language and folklore of the Turks of southern Siberia [Demonym "aza" $v$ yazyke I folklore turkov yuzhnoy Sibiri]. Siberian philological journal, 2, 40-53.

14. Onions, C. T. (2004). Oxford Dictionary of English Etymology. Oxford University Press, 1042.

15. Rassadin, V. I., Trophimova, S. M., Bold, L. (2018). Turkic-Mongolian Parallels among terms of spiritual culture in Mongolian languages [Turksko-mongolskyie paralleli sredi terminov dukhovnoy kultury $\mathrm{v}$ mongolskikh yazykakh]. Siberian philological journal, 3, 222-230.

16. Bahumaid, Showqi (2015). Lexical Borrowing: The Case of English Loanwords in Hadhrami. Arabic-International Journal of Language and Linguistics.

17. Yuldasheva, S. A. (2016). The influence of borrowings on the vocabulary of the language. Young scientist, 12, 1046-1048.

18. (1999). Webster's New World Dictionary 4th edition., MacMillon.

19. Webster's Third New International Dictionary of English Language, unabridged, with Seven 14.

20. Zaripova, A. , Fominykh A. (2015). Process of Economic Terms Internationalization (By Materials of the German, Russian and Tatar Languages). Journal of Sustainable Development, 8(4), 112-118.

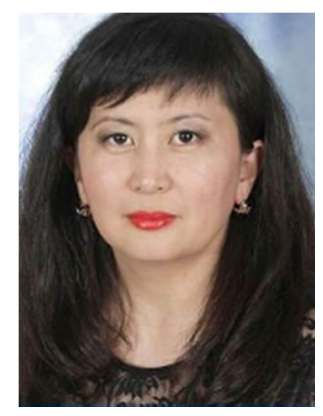

Хамитова Шайзат Амантаевна.

Преподаватель иностранных языков, кафеедра «Казахский, русский и иностранные языки»., Карагандинский индустриальный университет, пр. Республики 30, Темиртау, Карагандинская область, Казахстан, 101400.

E-mail: shaizat85@mail.ru

Khamitova Shaizat Amantayevna.

The Teacher of Foreign Languages, Department "Kazakh, Russian and Foreign Languages",

Karaganda state industrial university,

Republic Ave. 30, Temirtau, Karaganda region, Kazakhstan, 101400.

E-mail: shaizat85@mail.ru

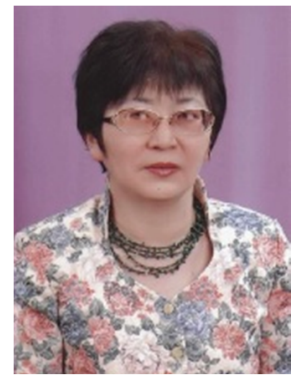

Адилова Алмагуль Советовна.

доктор филологических наук, профрессор, кафредра казахского языкознания,

Карагандинський університет імені академіка $€$. А. Букетова,

ул. Университетская, 28, Караганда, Республика Казахстан, 100028.

E-mail: adilova2010@mail.ru

\section{Adilova Almagul Sovetovna.}

Doctor of Philology, Professor, Department of Kazakh Linguistics,

E.A. Buketov Karaganda State University,

st. University, 28, Karaganda, The Republic of Kazakhstan, 100028.

E-mail: adilova2010@mail.ru

Scopus ID: 56610392700

Citation (APA):

Khamitova, Sh., Adilova, A. (2020). Language Adaptation of Turkisms in English. Engineering and Educational Technologies, 8 (3), 24-32. doi: https://doi.org/10.30929/2307-9770.2020.08.03.02

\section{Цитування (ДСТУ 8302:2015):}

Хамітова Ш., Аділова А. Мовна адаптація тюркізмів в англійській мові / Інженерні та освітні технології. 2020. Т. 8. № 3. С. 2432. doi: https://doi.org/10.30929/2307-9770.2020.08.03.02

Обсяг статmі: сторінок - 9 ; умовних друк. аркушів - 1,304. 